https://doi.org/10.18485/iipe_postsovjet.2021.ch6

Aсја Пентегова ${ }^{1}$

\title{
САРАДЊА ЕАЕУ И РЕПУБЛИКЕ СРБИЈЕ: ПЕРСПЕКТИВЕ САВРЕМЕНЕ ЕВРОАЗИЈСКЕ ИНТЕГРАЦИЈЕ
}

\begin{abstract}
Ancтракт: У чланку се истражује перспектива закљученог споразума о зони слободне трговине између Евроазијске економске уније и Републике Србије. Циљ истраживања је идентификовати позитивне и негативне тачке за Србију и Евроазијску економску унију приликом примене споразума о зони слободне трговине. Извршено је глобално и квалитативно истраживање о функционисању и интеракцији Евроазијске економске уније са Србијом и са земљама партнерима.

Евроазијска економска унија формира заједнички економски простор и спроводи заједничку политику о одређеним питањима на основу јединствене законске регулативе. Државе чланице Евроазијске економске уније формирају систем односа вредновања и оријентације једни према другима, као и према другим објектима међународних односа. На самиту у Астани, 2016. године, започети су преговори о унификацији трговинскоекономског режима, чији је резултат било потписивање Споразума о зони слободне трговине између Србије и ЕАЕУ, у октобру 2019. године. Након ратификације свих потписника режим слободне трговине ступио је на снагу 10. јула 2021. године.

Посебна пажња посвећена је положају Србије у систему регионалних међународних односа. Анализиран је проблем избора Србије између Европске уније и Евроазијске економске уније. Истакнути су позитивни аспекти сарадње са Евроазијском економском унијом. За Евроазијску економску унију закључивање споразума о зони слободне трговине има и економски (јачање трговинске и економске сарадње), и политички значај (проширење евроазијске интеграције изван постсовјетског простора).
\end{abstract}

\footnotetext{
${ }^{1}$ Асја Пентегова, саветник, Белоруски институт за стратешка истраживања, Минск, Белорусија, pentegova@bisr.by.
} 
Кључне речи: Евроазијска економска унија, зона слободне трговине, Република Србија, споразум, заједничко тржиште, међународни односи, економски односи, пројекат евроазијске интеграције.

Статус државе у данашње време, пре свега, одређује се његовом економском и војном снагом и материјалним ресурсима које има. Због тога, консолидација земаља чланица Евроазијске економске уније повећава економски потенцијал сваке земље појединачно и Уније као заједнице. Од почетка формирања Уније можемо говорити о интересовању за пројекат евроазијске интеграције од стране влада страних држава и регионалних међународних удружења. О томе сведочи низ меморандума које је Евроазијска економска комисија закључила последњих година.

Као једна од области сарадње за Евроазијску економску унију истиче се могућност закључивања меморандума споразума о сарадњи са земљама које изражавају жељу за повећањем економске интеракције са Унијом. Први споразум о зони слободне трговине закључен је 2015. године са Вијетнамом и покрива све области трговинске и економске сарадње. ${ }^{2}$ Једна од иновација садржаних у споразуму ЕАЕУ и Вијетнама је управо у повољном положају у погледу могућности примене посебних заштитних, компензационих и антидампиншких мера. У спровођењу антидампиншких и компензацијских истрага од стране земље која је закључила споразум са ЕАЕУ, она је дужна да појединачно разматра земље Уније и не примењује без потребе мере на целу унију. У одређеним неповољним ситуацијама то ће помоћи да се избегне потпуни прекид спољнотрговинске робне размене између земље потписника, с једне стране, и земаља чланица Уније, с друге стране.

Као алтернатива европском путу развоја у српском друштву, посебно у његовом русофилском окружењу, активно се промовише теза о перспективи сарадње са ЕАЕУ, узимајући у обзир блиски контакт држава чланица уније са Кином.

\footnotetext{
${ }^{2}$ Соглашение о свободной торговле между государствами-членами ЕАЭС и Социалистической Республикой Вьетнам, Internet, http://www.eurasiancommission. org/ru/act/trade/dotp, 14/05/2021.
} 
У српском јавном мњењу, Евроазијска економска унија сматра се пројектом стварања новог наднационалног објекта моћи, који ће постати веза између Европе и Азијско-пацифичког региона, а који има „дубоку геополитичку основу за уједињење Централног региона Евроазије“. Циљ пројекта је објединити не само бивши совјетски простор, већ и обједињавање осталих делова Евроазије у један савез „као алтернативу културним и политичким снагама Запада“.

На самиту у Астани 2016. године започети су преговори о уједињењу трговинско-економског режима, чији је резултат било потписивање Споразума о зони слободне трговине између Србије и EAEУ, у октобру 2019. године. Након ратификације од свих страна, режим слободне трговине је ступио на снагу 10. јула 2021. године.

Пре ратификације потписаног споразума од свих страна, на снази су били претходно закључени билатерални споразуми у односима са Србијом: Споразуми о зони слободне трговине са Руском Федерацијом, Републиком Белорусијом и Републиком Казахстан. Сличан преференцијални режим између Србије, Јерменије и Киргистана није био раније успостављен. Србији се овим споразумом отвара приступ тржишту од 183 милиона људи. Потписнице се споразумом обавезују да ће либерализовати међусобну трговину и да ће државе чланице ЕАЕУ омогућити српској роби равноправан приступ на своја тржишта.

Успешна интеграција не зависи од проналажења нове и оригиналне идеје, већ се заснива на претварању постојећих модела али, с обзиром на иновације које су уведене, одговорима на сталне изазове савременог света. Економске интеграционе уније такође могу смањити политичке и економске напетости у регионима.

У контексту закључења Споразума о зони слободне трговине између EAEУ и партнерских земаља, размотрићемо питање „вектора односа“ између држава чланица Уније и других земаља које утичу и на доношење одлука у ЕАЕУ и на формирање позиција Уније о одређеним економским, а понекад и политичким питањима. Поред тога, политичко-психолошка клима утиче на присуство или одсуство конфликтогеног потенцијала.

У процесу спровођења спољнополитичког курса државе теже да идентификују не само скуп проблема и стање „равнотеже снага“, већ такође формирају систем оцењивачких и оријентационих односа једних према другима, као и према другим објектима међународних односа. По 
мишљењу професора МГИМО Марка Арсенијевича Хрусталева, у најопштијем облику могу се разликовати три главна вектора формирања политичко-психолошке климе, фокусирани на међусобни однос држава. ${ }^{3}$

Вектор „пријатељ-непријатељ“ карактерише највећи степен напетости односа, који се супротставља „братским односима“ који се сматрају највећим степеном пријатељства. При формирању ове врсте односа немогуће је занемарити улогу историјског сећања и негативних догађаја из прошлости, који могу још дуго имати утицаја на политику одређених држава. Наравно, на основу циљева и принципа Уније, у ЕАЕУ није могуће пронаћи пример таквих односа. Вектор „пријатељ-непријатељ“ карактеришу постојеће или привремено прекинуте контрадикције између актера међународних односа. Као пример овог вектора можемо навести однос Русије и Сједињених Држава, који се развио још од периода „Хладног рата“. Све то време земље су непрестано у режиму ривалства. Чак и након завршетка „Хладног рата“ и распада СССР-а, САД је била једина држава која отворено изјавила свој глобални спољнополитички циљ - стварање „новог светског поретка“, промена и реструктурирање система међународних односа, „американизација“ света. ${ }^{4}$

Последњих година због увођења све више и више санкција ЕУ против држава чланица ЕАЕУ, посебно Русије и Белорусије, отвориле су се нове могућности за српску економију.

Евроазијска економска унија изједначава „равнотежу снага“, између Европе и Сједињених Држава, с једне стране, и Русије и држава чланица EAEУ, с друге стране. Питање супституције увоза може се решити путем „супституције увоза другог реда“, када се, због смањења удела западних земаља на тржиштима ЕАЕУ, појави прилика, на пример, за Србију да повећа извоз својих производа од националних произвођача и добављача.

Вектор „зависност-независност“ формира се на основу „равнотеже снага" између земаља, на јасној супериорности једног субјекта међународних односа над другим, при чему други има јасну политичку и економску зависност од лидера.

\footnotetext{
${ }^{3}$ Марк Хрусталёв, Анализ международных ситуаций и политическая экспертиза: очерки теории и методологии, М.: НОФМО, 2008, стр 232.

${ }^{4}$ Алексей Богатуров, Современная мировая политика: Прикладной анализ, М.: Аспект Пресс, 2010, стр. 592.
} 
Уговор ЕАЕУ од 2015. године обезбеђује спровођење координисане, договорене или заједничке политике државе чланице. Међутим, приликом формирања буџета Уније, део Русије је - 87\%. Росселкхознадзор је након ступања на снагу Уговора ЕАЕУ неколико пута уводио забрану увоза меса и млечних производа на територију Руске Федерације из Републике Белорусије. Међутим, ова забрана је у супротности са чланом 58 Уговора ЕАЕУ, који садржи једина ветеринарска и санитарна правила за све државе чланице ЕАЕУ. ${ }^{5}$ На састанку Евроазијске економске комисије, 9. јуна 2018, ово питање је размотрено и примећено је да уведена временска ограничења нису у складу са уговором ЕАЕУ. ${ }^{6}$

Историја савремених међународних односа указује на то да економски много јача држава није увек склона да узме у обзир интересе свог економског партнера. ${ }^{7}$ Стога, ако Руска Федерација настави да уводи једностране мере, које не одговарају једином закону за све државе чланице Уније, перспективе развоја економске интеграције биће под озбиљним питањем.

Вектор „поверење-неповерење“ настаје као последица конвенционалности политике, њене морално-етичке промене у складу са уговорима, споразумима, конвенцијама.

Ако постоји непоштовање уговора, споразума, конвенција, онда можемо говорити о формирању климе неповерења, у којој се другачија политика сматра непријатељском.

Односи Белорусије и Србије могу се сматрати примером односа „вектор поверења“" у којем не постоји очигледна супериорност једног од субјеката. Земље су везане једнаким билатералним економским и политичким односима који максимално задовољавају потребе и интересе обе државе и немају очигледан притисак на политички курс друге државе.

\footnotetext{
${ }^{5}$ Договор о Евразийском экономическом союзе, КонсультантПлюс. Россия, 29 маја 2014.

${ }^{6}$ ЕЭК: ограничения на ввоз в Россию белорусской молочки не соответствуют праву EAЭC, Internet, http://www.belta.by/economics/view/eek-ogranichenija-na-vvoz-v-rossijubelorusskoj-molochki-ne-sootvetstvujut-pravu-eaes-309880-2018/, 01/07/2021.

${ }^{7}$ Марк Хрусталёв, Анализ международных ситуаций и политическая экспертиза: очерки теории и методологии, М.: НОФМО, 2008, стр 232.
} 
У 2019. години спољнотрговинска робна размена између Републике Белорусије и Републике Србије износила је 148,6 милиона долара. Извоз је износио 80,6 милиона долара, увоз 68,0 милиона долара. Спољнотрговинска робна размена између Републике Белорусије и Републике Србије нестабилно се развија: 2009 - 53,3 милиона долара, 2010 - 116,4 милиона долара, 2011 - 145,4 милиона долара, 2012 -149,2 милиона долара, 2013 - 192,2 милиона долара, 2014 - 244,9 милиона долара, 2015 - 259,7 милиона долара, 2016 - 113,9 милиона долара, 2017 - 239,6 милиона долара, 2018 - 148,1 милиона долара, 2019 - 148,6 милиона долара.

Комбинација сва три вектора омогућава одређивање општег стања политичко-психолошке климе Евроазијске економске уније, у којој Унија мора да обавља своје активности. ${ }^{8}$

Неопходно је истаћи да што је повољнија политичко-психолошка клима, то ће бити мање проблема током активности ЕАЕУ у интересу својих држава чланица и партнерских држава. Најповољна клима може се додати у контексту трећег вектора, у стварању највеће могуће климе поверења. Што се тиче ситуације када односима доминирају две друге климе, можемо приметити да ће успешни односи и потрага за најефикаснијом политиком Уније по одређеним питањима бити ограничени због слабог регулисања и немогућности постизања консензуса о низу питања. Нико неће добровољно напустити своје интересе.

Пример Србије показује проблем избора између економске сарадње са Евроазијском економском унијом, с једне стране, и Европском унијом, с друге стране. Према резултатима истраживања јавног мњења, спроведеног још 2015. године, 61\% становништва земље мисли да Србија не припада ни Западу ни Истоку9.

У материјалу који је 2016. објавио Руски савет за међународне послове, предложена су три могућа начина развоја даљих односа Србије и ЕАЕУ, где је разматран најповољнији сценарио у коме је Србији

\footnotetext{
${ }^{8}$ Алексей Богатуров, Современная мировая политика: Прикладной анализ, М.: Аспект Пресс, 2010, стр. 592.

${ }_{9}^{9}$ Survey of Serbian Public Opinion, Center for Insights in Survey, Internet, http://www.iri. org/sites/default/files/wysiwyg/serbia_november_2015_poll_public_release.pdf, 11/05/2021.
} 
додељена улога моста између ЕУ и ЕАЕУ [7, стр. 21]. Међутим, у српској научној литератури дискусије на ову тему су мање развијене, а углавном позитивни и негативни аспекти сарадње са ЕАЕУ разматрају се у контексту будућег приступања Србије Европској унији.

Утицај евроатлантизма на друштвену, политичку и економску елиту у савременој Србији није само последица сталног утицаја Запада и његових савремених идеја већ, пре свега, резултат дугих, систематских и практичних акција на терену у већини сегмената друштва: стратешки оријентисани новац уложен у предузећа и компаније. Утицај евроатлантизма варира од стварања мрежа удружења, агената утицаја, лобистичких група, преко културне и образовне размене, до формирања група за утицај путем медијских структура и управљачког особља.

Са друге стране, ЕАЕУ и државе партнери представљају огромно тржиште за српску економију, које може постати и главни добављач и главно тржиште продаје. У неким областима трговинске и економске сарадње за робу из Србије тржиште Европске уније је и даље неприступачно због постојећих нецаринских баријера, конкурентности и цене робе. На основу тога, видљиве су перспективе отварања нових и додатних тржишта за српску економију на територијама држава чланица ЕАЕУ и држава партнера.

Током последњих деценија евроазијске државе су слабо покушавале да буду присутне на територији Србије како би на српским економским тржиштима били равноправни партнери. У сарадњи Русије и Србије, највећи део се односи на енергетски сектор и руске инвестиције у српску економију.

У складу са међународним споразумом, потписаним 2009. године између Русије и Србије, руска компанија Газпромнефт купила је 51\% акција Нафтне индустрије Србије. Ова продаја акција иностраном партнеру реализована је у складу са процесом приватизације државних компанија у Србији. ${ }^{10}$ Део руског гаса у укупној домаћој потрошњи Србије износи око 85\%. ${ }^{11}$ Србија не може без Русије, без њеног гаса и нафте.

${ }^{10}$ Драган Петровић, Ана Јокић, Енергетска политика Русије. Београд: Институт за међународну политику и привреду, 2015. - 240 с.

${ }^{11}$ Срећко Ђукић, Руски гас у Европи - од детанта до Јужног тока, Београд: Службени гласник, 2011, стр. 184. 
Према званичним изворима, до 90\% садржаја руско-балканских односа, на овај или онај начин, повезано је са енергетским сектором. ${ }^{12}$ Пролазак руског гасовода „Турски ток“ кроз територију Србије имаће позитиван ефекат на политички мир између балканских земаља, ојачавајући још увек крхки светски поредак у региону.

Према подацима које је објавила Развојна агенција Србије за 2020. годину, укупан извозни потенцијал Србије износи 1,3 милијарде потрошача. У 2020. години земље ЕАЕУ добиле су 5\% укупног извоза Србије. Лидери међу спољнотрговинским партнерима су државе чланице ЕУ - 67\% и земље ЦЕФТА - 17\%. ${ }^{13}$ Главни уговарачи су земље/удружења са којима постоје споразуми о зони слободне трговине (државе чланице ЦЕФТА, државе чланице ЕАЕУ, Турска), као и земље са којима постоји преференцијални услови за извоз (ЕУ, САД, Аустралија, Јапан) .

При томе, у поглављу 30 преговарачког досијеа о приступању Србије Европској унији, за могући улазак у ЕУ Србија мора да одустане од свих постојећих споразума о зони слободне трговине. ${ }^{14}$ Наведене обавезе за односе са ЕУ, кроз одређени пренос контроле над својом спољном политиком и губитком економских партнера, доводе до размишљања о перспективи изабраних стратегија. Још увек нису анализирани трошкови и добробити, нису препознате предности и недостаци који ће настати као резултат приступања земље Европској унији. Очигледно да постаје казус текућих преговора о уласку Србије у ЕУ, и закљученом споразуму о зони слободне трговине са ЕАЕУ.

Србија има статус кандидата за чланство у Европској унији, али паралелно она плански прати одабрану мултилатералну политику економске и политичке везе са земљама које нису државе чланице ЕУ, као што су, на пример, земље чланице ЕАЕУ.

\footnotetext{
${ }^{12}$ Op. cit.

${ }^{13}$ Развојна Агенција Србије аgencija Srbije. Internet, https://ras.gov.rs/podrskainvestitorima/zasto-srbija/slobodan-pristup-trzistu-od-11-milijarde-potrosaca 04/03/2021.

${ }^{14}$ European Neighbourhood Policy And Enlargement Negotiations, European Commission, Internet, https://ec.europa.eu/neighbourhood-enlargement/countries/detailed-countryinformation/serbia_en, 25/05/2021.
} 
Динамика развоја билатералних економских односа и анализа података Републичког завода за статистику Србије показују да је Русија у последњих шест година остала у првих пет спољнотрговинских партнера Србије. Последице коронавируса утицале су и на регионалне и међурегионалне ланце снабдевања, због чега је смањена спољнотрговинска робна размена између Русије и Србије у 2020. години.

Србија је заинтересована за либерализацију трговинске и економске сарадње са земљама ЕАЕУ у области роба попут памука, сира, дувана, шећера, пилетине, вина и аутомобила Фиат. ${ }^{15}$

Традиционални дефицит спољне трговине у Србији многи стручњаци објашњавају неразвијеним системом унутрашње економије који се углавном заснива на систему координације и сарадње српских привредника, предузећа, државних органа и регионалних/међународних организација на различитим нивоима.

У складу са Законом о спољнотрговинском пословању Републике Србије, Спољна трговина је „трговина робом и услугама и спровођење привредних активности страног правног лица у Републици Србији и националног субјекта у другој држави или царинском подручју“. ${ }^{16}$ Спољнотрговинска робна размена је „промет између домаћих и страних лица који се обавља на основу уговора закључених у складу са домаћим прописима и међународним уговорима“. ${ }^{17}$ Поред тога, „обављање привредних делатности обухвата директно улагање и инвестирање радова страног лица у Републици Србији, односно домаћег лица у другој држави или царинској територији“. ${ }^{18}$ Узимајући у обзир тренутно стање у српској

\footnotetext{
${ }^{15}$ Serbia to sign an Agreement with the Eurasian Economic Union, Karanovic and partners, Internet, https://www.karanovic-nikolic.com/knnews/Pages/2016/08/26/Serbia-to-signan-Agreement-with-the-Eurasian-Economic-Union.aspx, 25/06/2021.

${ }^{16}$ O спољнотрговинском пословању, Закон Републике Србије, 01 фебруара 2012, Службени гласник Републике Србије, Internet, https://www.paragraf.rs/propisi/ zakon_o_spoljnotrgovinskom_poslovanju.html, 25/06/2021.

${ }^{17}$ О спољнотрговинском пословању, Закон Републике Србије, 01 фебруара 2012, Службени гласник Републике Србије, Internet, https://www.paragraf.rs/propisi/ zakon_o_spoljnotrgovinskom_poslovanju.html, 25/06/2021.

${ }^{18}$ О спољнотрговинском пословању, Закон Републике Србије, 01 фебруара 2012, Службени гласник Републике Србије, Internet, https://www.paragraf.rs/propisi/zakon_ o_spoljnotrgovinskom_poslovanju.html, 25/06/2021.
} 
економији и равнотежу спољне трговине, потребна је нова снажна стратегија промоције извоза на државном нивоу, која би требало да модернизује институционалне капацитете за побољшање и регулисање извоза: укључивање инструмената и механизама за подршку компанијама а такође посвећивање више пажње административној подршци предузећа. Стратегија треба да пружи могућности за додатни квантитативни раст предузетника. Потребно је радити на побољшању нивоа образовања и помоћи представницима сектора малих и средњих предузећа.

Потписивање споразума Србије са ЕАЕУ о стварању зоне слободне трговине, као и низ званичних изјава председника Александра Вучића о могућности ревизије приоритета земље, указују на то да се разматрају и други вектори сарадње. Очигледно је да Европска унија више није једини наднационални пројекат који је користан за српску економију. Споразум о зони слободне трговине између Србије и ЕАЕУ пружа могућности за проширење пословних контаката и перспективе јединог тржишта Евроазијске економске уније за представнике српског бизниса. То ће у будућности проширити присуство и ојачати позицију Србије на пољу изградње спољнотрговинских односа у азијском региону.

\section{Библиографија}

Богатуров, Алексей, Современная мировая политика: Прикладной анализ, М.: Аспект Пресс, 2010, стр. 592.

Ђукић, Срећко, Руски гас у Европи - Од детанта до Јужног тока, Београд: Службени гласник, 2011, стр. 184.

Хрусталёв, Марк, Анализ международных ситуаций и политическая экспертиза: очерки теории и методологии, М.: НОФМО, 2008, стр 232.

Договор о Евразийском экономическом союзе, КонсультантПлюс. Россия, 29. маја 2014.

European Neighbourhood Policy And Enlargement Negotiations, European Commission, Internet, https://ec.europa.eu/neighbourhood-enlargement/ countries/detailed-country-information/serbia_en, 25/05/2021.

ЕЭК: ограничения на ввоз в Россию белорусской молочки не соответствуют праву ЕАЭС, Internet, http://www.belta.by/economics/ 
view/eek-ogranichenija-na-vvoz-v-rossiju-belorusskoj-molochki-nesootvetstvujut-pravu-eaes-309880-2018/, 01/07/2021.

Петровић, Драган, Јокић, Ана, Енергетска политика Русије. Београд: Институт за међународну политику и привреду, 2015, стр. 240.

Развојна Агенција Србије, agencija Srbije_Internet, https://ras.gov.rs/ podrska-investitorima/zasto-srbija/slobodan-pristup-trzistu-od-11milijarde-potrosaca 04/03/2021.

Serbia to sign an Agreement with the Eurasian Economic Union, Karanovic and partners, Internet, https://www.karanovic-nikolic.com/knnews/Pages/ 2016/08/26/Serbia-to-sign-an-Agreement-with-the-Eurasian-EconomicUnion.aspx, 25/06/2021.

Соглашение о свободной торговле между государствами-членами ЕАЭС и Социалистической Республикой Вьетнам, Internet, http:// www.eurasiancommission.org/ru/act/trade/dotp, 14/05/2021.

Survey of Serbian Public Opinion, Center for Insights in Survey, Internet, http://www.iri.org/sites/default/files/wysiwyg/serbia_november_2015_p oll_public_release.pdf, 11/05/2021.

О спољнотрговинском пословању, Закон Републике Србије, 01. фебруара 2012, Службени гласник Републике Србије, Internet, https:// www.paragraf.rs/propisi/zakon_o_spoljnotrgovinskom_poslovanju.html, 25/06/2021. 


\title{
COOPERATION BETWEEN THE EURASIAN ECONOMIC UNION AND THE REPUBLIC OF SERBIA: PERSPECTIVES OF CONTEMPORARY EURASIAN INTEGRATION
}

\begin{abstract}
The article explores the perspectives of the free trade agreement between the Eurasian Economic Union and the Republic of Serbia. The purpose of the research is to identify both positive and negative aspects for Serbia and the Eurasian Economic Union.

In the main part, the global qualitative investigation of the functioning and interaction of the Eurasian Economic Union with Serbia and with partner countries is carried out.

The Eurasian Economic Union creates a common market for goods, services, capital and labour within the Union and implements coordinated or agreed policies on certain issues on the basis of legal regulation. The Eurasian Union Member States form a system of evaluation-orientation relations with each other, and other objects of international relations. Negotiations on the unification of the trade and economic regimes began in 2016 at the Asana Summit. As a result, the Free Trade Agreement between Serbia and the EAEU was signed in October 2019. After ratification by all signatories, the free trade regime entered into force on July 10, 2021.

Particular emphasis is placed on Serbia's position in the system of regional international relations. The problem of Serbia's choice between the European Union and the Eurasian Economic Union has been analyzed. The benefits of cooperation with the Eurasian Economic Union are highlighted. For the Eurasian Economic Union, the conclusion of free trade agreements has both economic (intensification of trade and economic cooperation) and political significance (expansion of Eurasian integration beyond the post-Soviet space).

Keywords: The Eurasian Economic Union, a free trade zone, The Republic of Serbia, an agreement, a common market, international relations, economic relations, Eurasian integration project.
\end{abstract}

